\title{
ANALISIS PEMASARAN PUPUK UREA DI KABUPATEN PIDIE (STUDI KASUS PRODUK PT. PUPUK ISKANDAR MUDA ACEH UTARA)
}

\author{
(The Marketing Analysis Of Urea Fertilizer In Pidie (Case Study Product of PT. \\ Pupuk Iskandar Muda, North Aceh)
}

\author{
Zeveni Zulisma Sari ${ }^{1}$, Sofyan ${ }^{1}$, Edy Marsudi $^{*}$ \\ ${ }^{1}$ Program Studi Agribisnis, Fakultas Pertanian, Universitas Syiah Kuala
}

\begin{abstract}
Abstrak. Tujuan dari penelitian ini adalah untuk mengetahui dan menganalisis bentuk saluran pemasaran dan lembaga pemasaran pupuk urea PT. PIM Aceh Utara di Kabupaten Pidie dan menghitung margin pemasaran serta faktor yang berperan dalam kelangkaan pupuk urea.Penelitian ini menggunakan metode survey. Jumlah sampel dari pedagang besar adalah 4 orang, dipilih dengan metode sampel total atau sensus yaitu $100 \%$ dari jumlah populasi. Sedangkan pengambilan sampel pada pedagang pengecer dipilih dengan menggunakan metode Snowball Sampling yang dimulai dengan sedikit orang dan membesar sehubungan pergerakan penelitian dan untuk sampel petani dilakukan dengan menggunakan metode Cluster Sampling atau pengambilan sampel secara kelompok atau gugus. Hasil penelitian menunjukkan bahwa bentuk saluran pemasaran pupuk urea PT. PIM Aceh Utara di Kabupaten Pidie adalah bentuk saluran dua tingkat (Two Level Channel) yaitu dengan menggunakan dua perantara lembaga pemasaran seperti pedagang besar dan pedagang pengecer. Margin pemasaran di tingkat pedagang besar adalah Rp. $150 / \mathrm{Kg}$ lebih kecil dibandingkan dengan margin pemasaran tingkat pedagang pengecer yaitu Rp. 175/Kg. Terdapat beberapa faktor yang berperan dalam kelangkaan pupuk urea PT. PIM di Kabupaten Pidie, yaitu : realisasi penyaluran pupuk tidak sesuai dengan kebutuhan petani, adanya pihak-pihak yang melakukan penyimpangan atau kecurangan dan lemahnya pengawasan dari pihak produsen dan pemerintahan setempat.
\end{abstract}

Kata Kunci : Pemasaran, Saluran pemasaran, Margin pemasaran, Pupuk urea

\begin{abstract}
This research aim to obtain the information and to analyze the marketing channel and organization of urea fertilizer of PT. PIM North Aceh in Pidie district, and to count the marketing margin along with the factors that influence the lack of urea fertilizer. The type of the research was survey method. The number of the traders was which chosen by the totol sampling method or the $100 \%$ census of the population. The method used for choosing the retailers was snowball sampling that started from a few samples then grew up along with the research movement. Meanwhile, the method used for choosing the farmer sample was cluster sampling. The result of the study showed that the marketing channel which had two mediator organizations such as the big traders and the retailers. Marketing margin on the big traders' level was Rp. $150 / \mathrm{Kg}$ which was smaller than on the retailers' level which was Rp. $175 / \mathrm{Kg}$. There were three factors had roles in the lack of urea fertilizer in Pidie district: the realization of fertilizer distribution was not as the farmers' needs, fraud and the lack of supervision by the producer and the government.
\end{abstract}

Keywords: Marketing, Marketing Channel, Marketing Margin, Urea Fertilizer.

\section{PENDAHULUAN}

Pupuk merupakan salah satu sarana produksi pertanian yang memiliki peranan penting dalam mendukung program ketahanan pangan nasional sehingga ketersediaan pupuk mutlak diperlukan. Pembangunan pabrik pupuk dimaksudkan pemerintah untuk meningkatkan produktivitas dan kesejahteraan petani. Oleh karena itu pabrik pupuk diwajibkan untuk memenuhi kebutuhan pupuk dalam negeri sesuai dengan prinsip 6 (enam) tepat, yaitu : tepat mutu, jenis, waktu, harga, jumlah dan tempat (PT. Pupuk Iskandar Muda, 2014). 
Dalam rangka mewujudkan Ketahanan Pangan Nasional pupuk sangat berperan penting dalam peningkatan produktivitas dan produksi komoditas pertanian. Untuk meningkatkan kemampuan petani dalam penerapan pemupukan berimbang diperlukan subsidi pupuk. Atas dasar hal tersebut dan agar dalam pelaksanaan subsidi pupuk dapat berjalan baik, perlu menetapkan Kebutuhan dan Harga Eceran Tertinggi (HET) Pupuk Bersbusidi untuk Sektor Pertanian (Menteri Pertanian, 2013).

Permasalahan kelangkaan pupuk yang diakibatkan oleh disparitas harga, hal ini terjadi karena di Indonesia diberlakukan dua harga pupuk, yaitu pupuk subsidi untuk petani dan pupuk non subsidi untuk perusahaan perkebunan dan industri. Saat ini pemerintah menetapkan HET untuk pupuk urea bersubsidi sebesar Rp. 1800/Kg. Sedangkan harga pupuk non subsidi berkisar antara Rp. 2000/Kg sampai dengan Rp. 3000/Kg. Disparitas harga ini mendorong oknum-oknum distributor dan pedagang pupuk yang ingin meraup keuntungan sepihak yang melakukan kecurangan dengan menjual pupuk subsidi ke perusahaan perkebunan dan industri. Akibatnya petani kecil justru tidak kebagian pupuk bersubsidi.Kondisi ini diperparah lagi dengan adanya disparitas harga pupuk antara di dalam negeri dan di luar negeri.Saat ini harga pupuk di luar negeri mencapai US\$ 500/Ton, atau sekitar Rp. 5500/Kg. Peluang ini dimanfaatkan oleh banyak pihak untuk menyelundupkan pupuk ke luar negeri (PT. Pupuk Iskandar Muda, 2014).

PT. Pupuk Iskandar Muda (PT. PIM) merupakan salah satu perusahaan yang berkecimpung dalam usaha memproduksi pupuk, baik itu pupuk urea maupun amonia. Perusahaan ini bergerak dalam industri pupuk urea yang menghasilkan 1.725 Ton/hari, hal ini sangat dipengaruhi oleh fluktuasi harga bahan baku berupa gas, keadaan ini memaksa perusahaan untuk bekerja keras agar dapat terus berproduksi dalam jumlah yang telah ditentukan. Oleh sebab itu perusahaan harus memperbaiki aktivitas produksi, sehingga kelangsungan hidup perusahaan untuk berproduksi dapat dipertahankan.

Pada perusahaan seperti PT. Pupuk Iskandar Muda, sistem pemasaran sangat diutamakan agar kapasitas penyaluran hasil produksi perusahaan seperti pupuk yang utama dapat terpenuhi untuk patani lokal sekitar dan seluruh petani di Provinsi Aceh, apalagi saat ini produksi pupuk PT. PIM penyalurannya sampai ke Sumatera Utara, Sumatera Barat, Kalimantan Barat, Riau dan Kepulaun Riau.

Tabel 1. Rencana Alokasi dan Realisasi Penyaluran Pupuk Urea Bersubsidi PT.Pupuk Iskandar Muda Tahun 2013

\begin{tabular}{llrrr}
\hline No. & Wilayah Provinsi & Alokasi (Ton) & Realisasi (Ton) & $\begin{array}{c}\text { Persentase } \\
(\%)\end{array}$ \\
\hline 1. & Aceh & $71.318,00$ & $69.020,00$ & 96,7 \\
2. & Sumatera Utara & $162.450,00$ & $163.221,60$ & 100,47 \\
3. & Sumatera Barat & $72.020,00$ & $70.888,95$ & 98,4 \\
4. & Riau & $34.000,00$ & $34.000,00$ & 100 \\
5. & Kepulauan Riau & 280,00 & 85,60 & 30,57 \\
6. & Kalimantan Barat & $35.500,00$ & $35.500,00$ & 100 \\
\hline \multicolumn{2}{c}{ Total } & $375.568,00$ & $372.716,15$ & 99,24 \\
\hline
\end{tabular}

Sumber :PT. Pupuk Iskandar Muda Aceh Utara, 2014.

Analisis Pemasaran Pupuk Urea di Kabupaten Pidie (Studi Kasus Produk PT. Pupuk Iskandar 301 Muda Aceh Utara) (Zeveni Zulisma Sari, Edy Marsudi, Sofyan)

Jurnal Ilmiah Mahasiswa Pertanian Unsyiah, Vol. 2, No. 4, November 2017: 300-314 
Tabel 1. Menunjukkan jumlah alokasi dan penyaluran pupuk urea bersubsidi PT. PIM diseluruh wilayah pemasarannya, yaitu wilayah Aceh, Sumatera Utara, Sumatera Barat, Riau, Kepulauan Riau dan Kalimatan Barat. Jika dilihat Tabel 1. Jumlah alokasi dan penyaluran tertinggi adalah wilayah provinsi Sumatera Utara sebesar 163.221,60 Ton atau $100,47 \%$ dari jumlah alokasi 162.450,00 Ton. Sedangkan penyaluran terendah adalah wilayah provinsi Kepulauan Riau sebesar 85,60 Ton atau 30,57\% dari jumlah alokasi 280,00 Ton. Untuk wilayah provinsi Aceh jumlah realisasi penyaluran pupuk urea bersubsidi adalah 69.020,00 Ton atau 96,7\% dari jumlah alokasi 71.318,00 Ton.

Tabel 2. Rencana \& Realisasi Penyaluran \& Penjualan Pupuk Urea Bersubsidi Tahun 2013 Wilayah Provinsi Aceh

\begin{tabular}{rlrrr}
\hline & & \multicolumn{2}{c}{ Total } & Kabupaten \\
\cline { 3 - 4 } No. & \multicolumn{1}{c}{$\begin{array}{c}\text { Rencana } \\
\text { (Ton) }\end{array}$} & $\begin{array}{c}\text { Realisasi } \\
\text { (Ton) }\end{array}$ & Persentase $(\%)$ \\
\hline 1. & Sabang & 61,00 & - & - \\
2. & Banda Aceh & 254,00 & 211,00 & 83,07 \\
3. & Aceh Besar & $4.036,00$ & $4.236,00$ & 104,96 \\
4. & Pidie & $7.387,00$ & $7.037,00$ & 95,26 \\
5. & Pidie Jaya & $3.649,00$ & $3.740,00$ & 102,49 \\
6. & Bireuen & $6.065,00$ & $6.615,00$ & 109,07 \\
7. & Lhokseumawe & 990,00 & 555,00 & 56,06 \\
8. & Aceh Utara & $6.988,00$ & $9.061,00$ & 129,67 \\
9. & Aceh Timur & $5.548,00$ & $6.648,00$ & 119,83 \\
10. & Langsa & $1.151,00$ & $1.127,00$ & 97,91 \\
11. & Aceh Tamiang & $4.207,00$ & $4.044,00$ & 96,13 \\
12. & Aceh Jaya & $1.317,00$ & 434,00 & 32,95 \\
13. & Aceh Barat & $3.361,00$ & 941,00 & 28,00 \\
14. & Nagan Raya & $3.516,00$ & $2.961,00$ & 84,22 \\
15. & Simuelu & $1.024,00$ & 60,00 & 5,86 \\
16. & Aceh Barat Daya & $2.995,00$ & $1.235,00$ & 41,24 \\
17. & Aceh Selatan & $3.367,00$ & $1.594,00$ & 47,34 \\
18. & Aceh Singkil & $1.626,00$ & $2.026,00$ & 124,60 \\
19. & Subulussalam & $1.256,00$ & $1.426,00$ & 113,54 \\
20. & Bener Meriah & $1.712,00$ & $1.295,00$ & 75,64 \\
21. & Aceh Tengah & $1.613,00$ & $1.150,00$ & 71,30 \\
22. & Gayo Lues & $1.873,00$ & $2.016,00$ & 107,63 \\
23. & Aceh Tetanggara & $7.322,00$ & $10.608,00$ & 144,88 \\
\hline & & $71.318,00$ & $69.020,00$ & \\
\hline & & & & $96,78 \%$ \\
\hline
\end{tabular}

Sumber : PT.Pupuk Iskandar Muda, 2014

Dapat dilihat pada Tabel 2. Penjualan pupuk urea untuk seluruh kabupaten di provinsi Aceh sudah cukup memadai meskipun adanya nilai naik turun dari jumlah realisasi yang telah direncanakan. Total penjualan pupuk urea di Aceh adalah sebesar 69.020,00 Ton dari jumlah realisasi sebesar 71.318,00 Ton atau sekitar

Analisis Pemasaran Pupuk Urea di Kabupaten Pidie (Studi Kasus Produk PT. Pupuk Iskandar 302 Muda Aceh Utara) (Zeveni Zulisma Sari, Edy Marsudi, Sofyan)

Jurnal Ilmiah Mahasiswa Pertanian Unsyiah, Vol. 2, No. 4, November 2017: 300-314 
96,78\% dari rencana yang telah ditetapkan. Jika dilihat dari total persentase penjualan pupuk urea yang hampir 100\% dari realisasinya, kasus kelangkaan pupuk urea tidak mungkin terjadi. Tetapi jika dilihat dilapangan, kelangkaan pupuk masih saja terjadi di seluruh kabupaten termasuk kabupaten Pidie yang jumlah penjualannya termasuk kedalam tiga tertinggi di Aceh yaitu 7.037,00 Ton. Menurut data BPS Kabupaten Pidie Tahun 2014, Kabupaten Pidie merupakan salah satu sentra produksi padi di Aceh. Tercatat pada tahun 2013 luas panen padi Kabupaten Pidie adalah 43,76 ribu hektar, sedikit meningkat dibandingkan luas panen pada tahun 2012 yang seluas 43,69 ribu hektar, aktifitas penanaman dapat dijumpai di semua kecamatan kecuali kecamatan Kota Sigli. inilah yang menjadi penyebab permintaan pupuk urea untuk Kabupaten Pidie termasuk kedalam tiga tertinggi di Provinsi Aceh.

Pemasaran merupakan salah satu dari kegiatan pokok yang harus dilakukan oleh para pengusaha termasuk pengusaha tani dalam usahanya untuk mempertahankan kelangsungan hidupnya, untuk mendapatkan laba, dan untuk berkembang. Berhasil tidaknya usaha tersebut sangat bergantung pada keahliannya dibidang pemasaran, produksi, keuangan dan sumber daya manusia (Firdaus, 2010).Ada beberapa permasalahan yang dihadapi dalam pengadaan pupuk, antara lain masalah harga, pemasaran, permodalan, pedagang maupun petani. Dalam hal ini masalah pemasaran merupakan masalah yang penting, karena dalam pemasaran ini melingkupi berbagai masalah seperti harga, tataniaga, distribusi, kelangkaan pupuk dan sebagainya.Dari latar belakang yang telah dipaparkan diatas maka penulis merasa tertarik untuk membuat penelitian yang dituangkan dalam sebuah karya ilmiah dengan judul "Analisis Pemasaran Pupuk Urea di Kabupaten Pidie ( Study Kasus Produk PT. Pupuk Iskandar Muda Aceh Utara)". Tujuan dari penelitian ini adalah 1) Untuk mengetahui bentuk saluran pemasaran pupuk urea PT. PIM 2) Untuk mengetahui perbedaan margin pemasaran yang diterima oleh lembaga pemasaran 3) Untuk mengetahui faktor-faktor yang berperan dalam kelangkaan pupuk urea di Aceh khusunya Kabupaten Pidie.

\section{METODE PENELITIAN}

Penelitian ini dilakukan di kabupaten Pidie.Penentuan lokasi ini dilakukan dengan secara sengaja (purposive sampling) berdasarkan pertimbangan bahwa kabupaten Pidie merupakan salah satu sentra produksi padi di Aceh yang kebutuhan pupuk urea termasuk dalam tingkat ke tiga tertinggi di Aceh.Penelitian berlangsung pada bulan Desember 2014 sampai bulan Mei 2015.

Metode dasar yang digunakan dalam penelitian ini adalah metode survey, yaitu penyelidikan yang diadakan untuk memperoleh fakta-fakta dari gejala-gejala yang ada dan mencari keterangan-keterangan secara factual, baik tentang institusi social, ekonomi maupun politik dari suatu kelompok atau suatu daerah (Nazir, 2005).

Teknik penentuan daerah sampel dalam penelitian ini berdasarkan pada kriteria tertentu (Purposive Sampling) yaitu daerah sampel merupakan sentra salah satu daerah yang kebutuhan pupuk urea tertinggi di Aceh. Berdasarkan kriteria tersebut maka peneliti secara sengaja memilih PT. Pupuk Iskandar Muda Aceh Utara sebagai daerah atau tempat penghasil pupuk urea (produk) dan Kabupaten Pidie

Analisis Pemasaran Pupuk Urea di Kabupaten Pidie (Studi Kasus Produk PT. Pupuk Iskandar 303 Muda Aceh Utara) (Zeveni Zulisma Sari, Edy Marsudi, Sofyan)

Jurnal Ilmiah Mahasiswa Pertanian Unsyiah, Vol. 2, No. 4, November 2017: 300-314 
ditunjuk secara sengaja (Purposive Sampling) sebagai daerah populasi dan daerah pengambilan sampel, karena kabupaten Pidie merupakan salah satu daerah pemasaran pupuk urea PT. PIM yang tertinggi di provinsi Aceh, memiliki lembaga pemasaran yang terdiri dari 4 pedagang besar dan 108 pedagang pengecer yang tersebar di 23 kecamatan sehingga pupuk urea dapat tersalurkan dengan baik ke seluruh desa di kabupaten Pidie yang berjumlah 686 desa.

Tabel 3. Jumlah Populasi pada Masing-masing Lembaga Pemasaran Pupuk Urea PT. PIM di Kabupaten Pidie Tahun 2014

\begin{tabular}{clc}
\hline No & \multicolumn{1}{c}{ Lembaga Pemasaran } & Jumlah Populasi (orang) \\
\hline 1. & Pedagang Besar & 4 \\
2. & Pedagang Pengecer & 108 \\
3. & Gapoktan & 686 \\
\hline
\end{tabular}

Sumber :PT. Pupuk Iskandar Muda, 2015

Berdasarkan Tabel 3. Dapat dilihat jumlah populasi lembaga pemasaran pupuk urea di Kabupaten Pidie terdiri dari 4 pedagang besar, 108 pedegang pengecer yang tersebar diseluruh kecamatan di kabupaten Pidie yaitu 23 kecamatan, dengan jumlah desa 686 dan Gabungan Kelompok Tani (Gapoktan) juga berjumlah 686. Tentu saja dengan jumlah populasi lembaga pemasaran tersebut PT. PIM dengan sangat mudah dapat menyalurkan pupuk urea sampai ke tangan petani-petani dengan bantuan lembaga pemasaran.Sehingga kelangkaan pupuk bukan menjadi masalah terdepan.

Tabel 4. Jumlah Populasi dan Sampel pada Masing-masing Lembaga Pemasaran Pupuk Urea PT. PIM di Kabupaten Pidie Tahun 2014

\begin{tabular}{cccc}
\hline No. & Lembaga Pemasaran & $\begin{array}{c}\text { Jumlah Populasi } \\
\text { (orang) }\end{array}$ & $\begin{array}{c}\text { Jumlah Sampel } \\
\text { (orang) }\end{array}$ \\
\hline 1. & Pedagang Besar & 4 & 4 \\
2. & Pedagang Pengecer & 108 & 8 \\
3. & Gapoktan & 686 & 16 \\
\hline \multicolumn{4}{c}{ Total } \\
\hline
\end{tabular}

Sumber : PT. Pupuk Iskandar Muda, 2015

Dari Tabel 4. dapat diketahui banyaknya jumlah populasi dan sampel dari pihak-pihak yang terlibat dalam penelitian ini. Dimana banyak sampel untuk pedagang besar diambil dengan menggunakan metode sampel total (total sampling) atau sensus, penggunaan metode ini berlaku jika anggota populasi relative kecil, karena dalam penelitian ini jumlah populasi untuk pedagang besar terbilang kecil yaitu 4 orang maka terpilihlah seluruh jumlah populasi sebagai sampel. Sampel untuk pedagang pengecer dipilih dengan menggunakan metode Snowball Sampling, yaitu dengan cara mengidentifikasi dan mengambil sampel lewat suatu jaringan yang didasarkan pada analogi bola salju, yaitu dimulai dalam ukuran kecil, tetapi seiring proses, jumlahnya membesar. Snowball sampling adalah teknik multi tahap, yang dimulai dengan sedikit orang dan membesar sehubungan pergerakan penelitian. Teknik penentuan sampel untuk petani menggunakan Cluster Sampling atau pengambilan sampel secara kelompok atau gugus, pada teknik ini digunakan

Analisis Pemasaran Pupuk Urea di Kabupaten Pidie (Studi Kasus Produk PT. Pupuk Iskandar 304 Muda Aceh Utara) (Zeveni Zulisma Sari, Edy Marsudi, Sofyan)

Jurnal Ilmiah Mahasiswa Pertanian Unsyiah, Vol. 2, No. 4, November 2017: 300-314 
populasi yang heterogen.Pada populasi ini terdiri beberapa area didalamnya mengandung unit populasi yang heterogen. Peneliti tidak mendaftar semua anggota yang ada dalam populasi, tetapi cukup mendaftar banyaknya kelompok dalam populasi kemudian mengambil sampel dari kelompok tersebut, dimana pemilihan responden di tingkat petani dilakukan dengan cara memilih kelompok yang menjadi sampel dari elemen - elemen dalam kelompok tersebut, peneliti hanya mengambil 2\% dari populasi tersebut dari 686 Gapoktan menjadi 16 Gapoktan (orang).

\section{Analisis Data}

Pengujian Hipotesis 1, akan dianalisis dengan menggunakan metode analisis deskriptif yang memaparkan beberapa saluran pemasaran pupuk urea yang berjalan di Kabupaten Pidie.

Pengujian Hipotesis 2, akan dianalisis dengan menghitung biaya pemasaran, margin pemasaran, share margin dan propit margin yang diterima masing-masing oleh perusahaan, pedagang distributor dan pedagang pengecer.

Untuk menghitung share margin, digunakan rumus :

Untuk menguji hipotesis diuji dengan menggunakan analisis margin (Azzaino, 1982) dengan model sebagai berikut :

Keterangan :

$$
M P=\mathrm{HJ}-\mathrm{HB}
$$

$$
\begin{array}{ll}
\mathrm{MP} & =\text { Margin Pemasaran }(\mathrm{Rp} / \mathrm{Kg}) \\
\mathrm{HJ} & =\text { Harga Jual }(\mathrm{Rp} / \mathrm{Kg}) \\
\mathrm{HB} & =\text { Harga Beli }(\mathrm{Rp} / \mathrm{Kg})
\end{array}
$$

Untuk menghitung Profit Margin, digunakan rumus (Azzaino, 1982), yaitu :

$$
P M=M P-B P
$$

Keterangan :

$$
\begin{aligned}
\mathrm{PM} & =\text { Profit Margin }(\%) \\
\mathrm{MP} & =\text { Margin Pemasaran }(\mathrm{Rp} / \mathrm{Kg}) \\
\mathrm{BP} & =\text { Biaya Pemasaran }(\mathrm{Rp})
\end{aligned}
$$

Untuk menghitung share margin, digunakan rumus (Umar, 2001) yaitu sebagai berikut :

Keterangan :

$$
S m=\frac{P p}{P k} \times 100 \%
$$

$$
\begin{array}{ll}
\mathrm{Sm} & =\text { Share Margin dihitung dalam persen }(\%) \\
\mathrm{Pp} & =\text { Harga yang dibayar pedagang } \\
\mathrm{Pk} & =\text { Harga Yang dibayarkan oleh konsumen akhir }
\end{array}
$$

Pengujian Hipotesis 3, akan dianalisis dengan menggunakan metode analisis deskriptif yang memaparkan beberapa faktor penyebab terjadinya kelangkaan pupuk di Kabupaten Pidie.

\section{HASIL PENELITIAN DAN PEMBAHASAN Pemasaran Pupuk Urea PT. PIM}

Sesuai dengan hasil penelitian dilapangan, dalam memasarkan pupuk urea, PT. PIM menerapkan peraturan tertentu untuk dapat membeli pupuk urea.Aturan

Analisis Pemasaran Pupuk Urea di Kabupaten Pidie (Studi Kasus Produk PT. Pupuk Iskandar 305 Muda Aceh Utara) (Zeveni Zulisma Sari, Edy Marsudi, Sofyan)

Jurnal Ilmiah Mahasiswa Pertanian Unsyiah, Vol. 2, No. 4, November 2017: 300-314 
tersebut berisi tentang persyaratan tertentu yang harus dilengkapi guna untuk dapat membeli pupuk urea dan menjualnya kembali. Rencana Definitif Kebutuhan Kelompok Tani (RDKK) adalah pesanan kelompok tani terhadap sarana produksi pertanian dan biaya lainnya untuk satu musim tanam sebagai hasil dari musyawarah kelompok tani yang memuat jenis, jumlah, jadwal waktu yang dibutuhkan dan sumber dana untuk pembeliaannya baik secara swadana maupun kredit.

RDKK Pupuk Bersubsidi merupakan rencana kebutuhan pupuk bersubsidi untuk satu tahun yang disusun berdasarkan musyawarah anggota kelompok tani sebagai alat pesanan pupuk bersubsidi kepada gabungan kelompok tani atau penyalur saranan produksi pertanian.Hanya Pedagang Besar yang ditunjuk oleh PT. PIM dapat membeli pupuk urea dengan membawa RDKK dalam bentuk tertulis yang didalamnya terdapat jumlah kebutuhan pupuk dan luas lahan pertanian.Pemasaran pupuk urea di Kabupaten Pidie berjalan sesuai dengan aturan yang telah dikeluarkan oleh pemerintah setempat. Pedagang besar membeli pupuk urea dalam jumlah yang relative besar, kemudian dijual kembali kepada pedagang pengecer yang membeli dalam jumlah relative sedang dan menjualnya lagi kepada petani dalam jumlah pembelian yang kecil tergantung pada kebutuhan produksi pertanian tidak sesuai dengan Harga Eceran Tertinggi (HET) yaitu Rp. 1.800/Kg atau Rp. 90.000/Sak, melainkan dengan harga Rp. 1.900/Kg atau Rp. 95.000/sak. Pada setiap pembelian atau penembusan pupuk urea disemua gudang baik digudang produsen, pedagang besar dan kios pedagang pengecer harus dilengkapi atau membawa RDKK sebagai alat penembusan pupuk. Berikut gambaran tentang alur permintaan pupuk urea bersubsidi PT. PIM, yaitu :

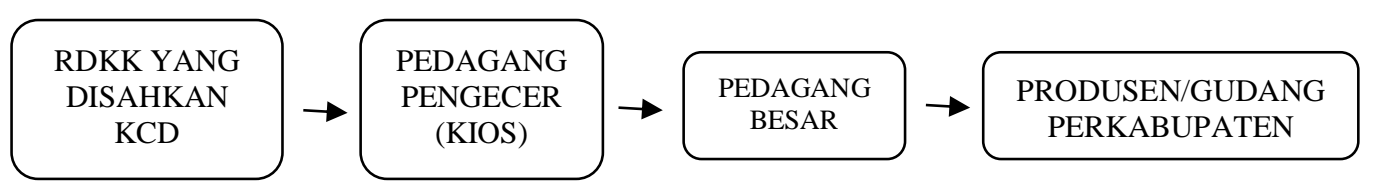

Gambar 1. Skema Alur Permintaan Pupuk Urea Bersubsidi

Dijelaskan bahwa permintaan pupuk oleh petani melalui RDKK yang disahkan KCD (Kepala Cabang Dinas) akan diserahkan ke kios pedagang pengecer lalu ke pedagang besar diteruskan ke gudang produsen yang ada pada setiap tempat di kabupaten. Adapun alur penyediaan pupuk urea akan digambarkan pada bagan berikut ini :

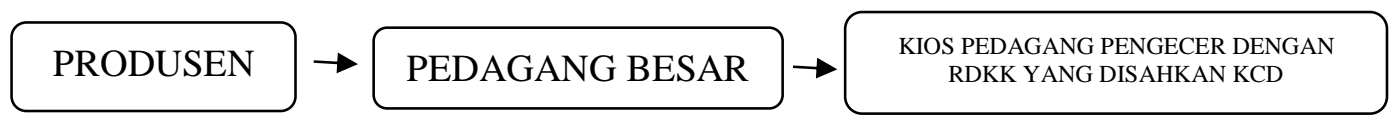

Gambar 2. Skema Alur Penyediaan Pupuk Urea Bersubsidi

Dapat dilihat bahwa produsen pupuk urea dalam penelitian ini adalah PT. PIM akan memyediakan semua kebutuhan pupuk urea sesuai dengan jumlah permintaan yang tedata pada RDKK ke gudang pedagang besar dan selanjutnya akan diteruskan oleh pedagang besar ke kios pedagang pengecer. Pedagang pengecer harus menunjukkan RDKK kepada pedagang besar sebagai alat atau syarat pembelian pupuk urea bersubsidi yang didalamnya berisikan pendataan kelompok tani yang berhak menerima bantuan pupuk bersubsidi tersebut. Alur pembelian akan digambarkan pada skema berikut ini :

Analisis Pemasaran Pupuk Urea di Kabupaten Pidie (Studi Kasus Produk PT. Pupuk Iskandar 306 Muda Aceh Utara) (Zeveni Zulisma Sari, Edy Marsudi, Sofyan)

Jurnal Ilmiah Mahasiswa Pertanian Unsyiah, Vol. 2, No. 4, November 2017: 300-314 
Ketua Kelompok Tani dengan membawa RDKK

\section{KIOS RESMI PEDAGANG PENGECER}

Gambar 3. Skema Alur Pembelian Pupuk Urea Bersubsidi

Gambar 3.Diatas menunjukkan berhasilnya tujuan pemasaran dari PT. PIM yaitu menyalurkan pupuk urea hingga sampai ke tangan konsumen akhir.Dimana konsumen akhir yang dimaksud tersebut adalah petani. Disini petani akan mendapatkan atau membeli pupuk urea bersubsidi pada kios pedagang pengecer dengan membawa RDKK yang telah disahkan oleh lurah atau pemerintah setempat. Hanya petani yang tercantum namanya didalam RDKK tersebutlah yang berhak untuk mendapatkan pupuk urea bersubsidi dari PT. PIM tersebut.

\section{Saluran Pemasaran Pupuk Urea PT. PIM}

Pemasaran merupakan serangkaian kegiatan yang dilakukan meliputi perencanaan dan pendistribusian barang dan jasa yang dilakukan oleh produsen ke konsumen akhir sehingga tujuan kedua pihak tercapai.Penyaluran pupuk sangat berperan penting dalam mencapai tujuan akhir dari pemasaran. Yang dimaksud dengan penyaluran dalam penelitian ini adalah proses pendistribusian pupuk urea bersubsidi dari PT. PIM sampai dengan Kelompok Tani atau Petani sebagai konsumen akhir. Berikut gambar mekanisme perencanaan penyaluran pupuk bersubsidi PT. PIM sebelum pendistribusian tersebut berjalan, yaitu :

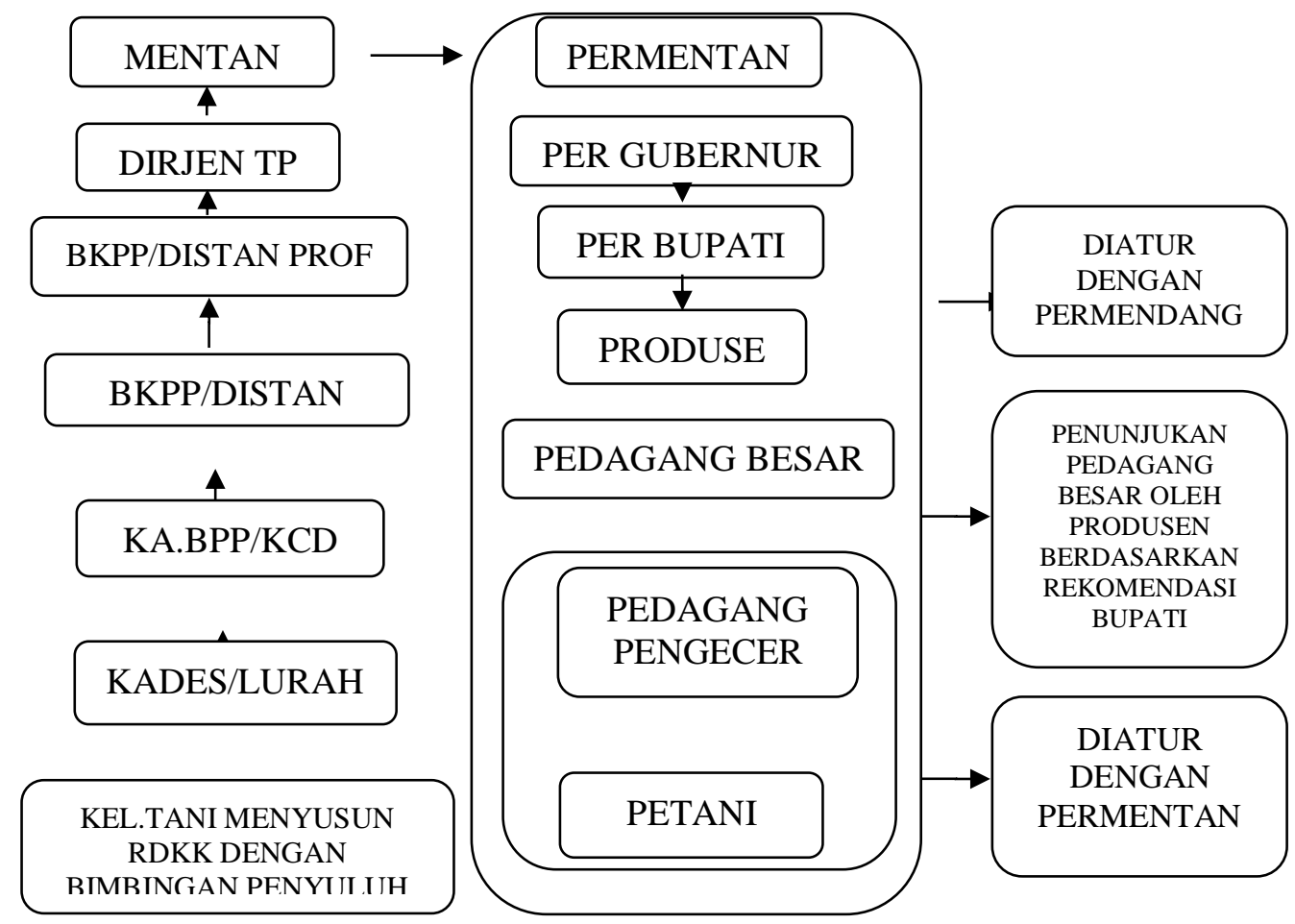

Gambar 4. Alur Perencanaan Kebutuhan dan Alur Pendistribusian Pupuk Urea Bersubsidi PT. PIM (PT. Pupuk Iskandar Muda, 2015)

Analisis Pemasaran Pupuk Urea di Kabupaten Pidie (Studi Kasus Produk PT. Pupuk Iskandar 307 Muda Aceh Utara) (Zeveni Zulisma Sari, Edy Marsudi, Sofyan)

Jurnal Ilmiah Mahasiswa Pertanian Unsyiah, Vol. 2, No. 4, November 2017: 300-314 
Berdasarkan Gambar 4. Diatas merupakan mekanisme perencanaan dan penyaluran pupuk bersubsidi yang sesuai dengan peraturan perdagangan No. 17/MDAG/PER/6/2011, tentang pengadaan dan penyaluran pupuk bersubsidi untuk sector pertanian. Dalam upaya memperoleh pupuk bersubsidi petani harus mengajukan RDKK yang disusun dibawah bimbingan penyuluh pertanian, kemudian RDKK yang telah disusun tersebut ditanda tangani oleh Lurah setempat, lalu disahkan oleh KCD (Kepala Cabang Dinas) pertanian kecamatan yang dilanjutkan kepada Dinas Pertanian tingkat Kabupaten kemudian kepada Dinas Pertanian tingkat Provinsi. Setelah dari Dinas Pertanian Provinsi akan dilanjutkan pengesahan oleh Direktorat Jendral Tanaman Pangan yang selanjutnya diteruskan kepada Mentri Pertanian dari sini dikeluarkanlah Peraturan Mentri Pertanian untuk penyaluran pupuk urea bersubsidi, yang dilanjutkan dikeluarkannya Peraturan Gubernur dan akan diteruskan ke Kepala Tingkat Provinsi (Bupati). Bupati juga akan mengeluarkan perarturan Bupati yang akan diserahkan ke Industri yang menyediakan pupuk urea untuk Provinsi Aceh yaitu PT. Pupuk Iskandar Muda (PIM). Lalu PT. PIM akan memilih Pedagang Besar berdasarkan rekomendasi dari Bupati. Seluruh peraturan peraturan dalam perencanaan penyaluran pupuk urea tersebut diatur dalam Peraturan Mentri Perdagangan. Kemudian pedagang besar akan memilih atau menunjukkan pedagang pengecer dan petani yang diatur dengan Peraturan Mentri Pertanian sehingga seluruh mekanisme perencanaan dan penyaluran pupuk dapat terlaksana dengan baik. Adapun alur pengajuan, realisasi dan penyaluran pupuk urea bersubsidi dapat dilihat pada gambar berikut ini :

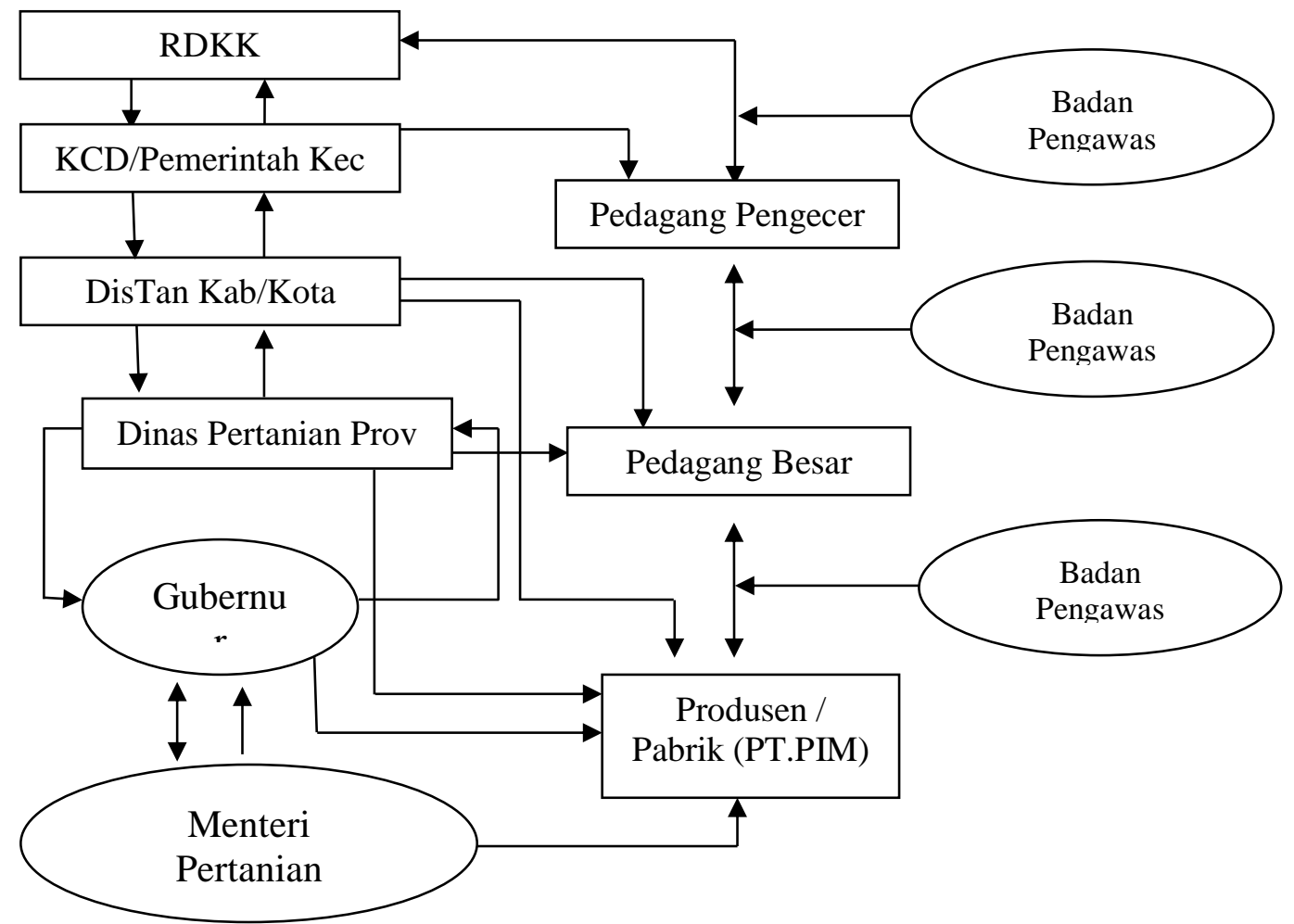

Gambar 5. Alur Pengajuan, Realisasi dan Penyaluran Pupuk Urea Bersubsidi PT. Pupuk Iskandar Muda, 2015

Analisis Pemasaran Pupuk Urea di Kabupaten Pidie (Studi Kasus Produk PT. Pupuk Iskandar 308 Muda Aceh Utara) (Zeveni Zulisma Sari, Edy Marsudi, Sofyan)

Jurnal Ilmiah Mahasiswa Pertanian Unsyiah, Vol. 2, No. 4, November 2017: 300-314 
Dari gambar 5.diatas dapat dilihat alur atau skema pengajuan, realisasi dan penyaluran pupuk urea bersubsidi pada PT. PIM. Sebelum pupuk disalurkan, terlebih dahulu mengajukan permintaan kebutuhan pupuk urea dengan pendataan melalui RDKK.Pengajuan tersebut dibuat oleh petani yang didalamnya berisi kuota kebutuhan pupuk urea, yang selanjutnya di ajukan kepada produsen pupuk urea yaitu PT. PIM dengan jasa perantara pemerintah setempat dan pedagang besar. Setelah PT. PIM menerima surat keterangan dari Gubernur atau pemerintah setempat, barulah PT. PIM mulai menyalurkan pupuk urea bersubsidi melalui perantara lembaga pemasaran yaitu pedagang besar, kemudian dari pedagang besar kepada pedagang pengecer dan kemudian dari pedagang pengecer petani dapat menebus pupuk urea dengan membawa RDKK.

Dalam memasarkan pupuk urea, terdapat 2 lembaga pemasaran yang terlibat didalamnya. Hasil dari penelitian menunjukkan saluran pemasaran pupuk urea bersubsidi PT. PIM di Kabupaten Pidie hanya terdapat satu tipe saluran, yaitu :

PT. PIM (Produsen) $\Rightarrow$ Pedagang Besar (Distributor) $\Rightarrow$ Pedagang Pengecer (Kios) $\Rightarrow$ Gapoktan (Konsumen)

Gambar 6. Skema Saluran Pemasaran Pupuk Urea Subsidi PT. PIM

Bentuk saluran pemasaran pada Gambar 6. diatas adalah saluran pemasaran penjualan pupuk urea dari PT. PIM (produsen) kepada Pedagang Besar lalu diteruskan oleh Pedagang Besar kepada Pedagang Pengecer setelah itu baru dilanjutkan penjualan kepada Gapoktan sebagai konsumen akhir dalam penyaluran tersebut. Pembelian pupuk urea tersebut harus diwajibkan dengan membawa atau menunjukan RDKK yang sudah disahkan oleh Gubernur atau Pemerintahan dibidang pangan dan pertanian. Dalam upaya penebusan pupuk urea bersubsidi pada kios pedagang pengecer, petani harus membayar dengan jumlah harga $\mathrm{Rp}$. 1.900-,/Kg, harga tersebut tidak sesuai dengan Harga Eceran Tertinggi (HET) yang telah ditetapkan oleh Menteri Pedagangan Republik Indonesia yang tertulis didalam Undang-undang yaitu Rp. 1.800/Kg.

Adapun tingkat saluran pemasaran pupuk urea adalah bentuk saluran dua tingkat (two level channel) yaitu :

Produsen (PT. PIM) $\Rightarrow$ Pedagang Besar $\Rightarrow$ Pedagang Pengecer $\Rightarrow$ Gapoktan (konsumen akhir)

Gambar 7. Skema Bentuk Saluran 2 Tingkat (Two Level Channel) Pupuk Urea PT.PIM

Dari Gambar 7. menujukkan bahwa produsen atau PT. PIM menggunakan dua lembaga pemasaran sebagai perantara PT. PIM dalam menyalurkan pupuk urea hingga sampai ke konsumen akhir yang dimaksudkan sebagai konsumen akhir adalah petani. Pedagang besar membeli atau memasok pupuk urea dalam jumlah

Analisis Pemasaran Pupuk Urea di Kabupaten Pidie (Studi Kasus Produk PT. Pupuk Iskandar 309 Muda Aceh Utara) (Zeveni Zulisma Sari, Edy Marsudi, Sofyan)

Jurnal Ilmiah Mahasiswa Pertanian Unsyiah, Vol. 2, No. 4, November 2017: 300-314 
besar sesuai dengan jumlah yang telah ditentukan oleh dinas setempat yang terlebih dahulu mendata atau mensurvey ke lapangan. Pedagang pengecer hanya memasok atau membeli pupuk dalam skala kecil sesuai dengan kebutuhan pupuk urea per kecamatan saja yang telah ditentukan oleh pedagang besar.Gakpoktan (petani) membeli pupuk hanya pada kios-kios pedagang pengecer yang sesuai dengan yang ditunjuk oleh pedagang besar.

\section{Margin Pemasaran Pupuk Urea}

Adapun untuk mengetahui margin pemasaran dan profit margin pada pedagang besar dan pedagang pengecer dapat dilihat pada Tabel 5 berikut ini :

Tabel 5. Analisis Profit Margin dan Margin Pemasaran Pada Pemasarsan Pupuk Urea PT. PIM di Kabupaten Pidie

\begin{tabular}{|c|c|c|c|c|}
\hline No & $\begin{array}{c}\text { Lembaga dan Harga/Biaya } \\
\text { Pemasaran }\end{array}$ & $\begin{array}{c}\text { Biaya } \\
(\mathrm{Rp} / \mathrm{Kg})\end{array}$ & $\begin{array}{c}\text { Persentase } \\
(\%)\end{array}$ & $\begin{array}{c}\text { Share } \\
\text { Margin (\%) }\end{array}$ \\
\hline \multirow[t]{5}{*}{1.} & Produsen & & & \\
\hline & Harga Jual & 1.575 & & \\
\hline & Karung Goni & 100 & & \\
\hline & Muat & 25 & & \\
\hline & Profit Margin & 1.450 & 92 & \\
\hline \multirow[t]{8}{*}{2.} & Pedagang Besar & & & 91 \\
\hline & Harga Jual & 1.725 & & \\
\hline & Bongkar & 25 & & \\
\hline & Muat & & & \\
\hline & & 25 & & \\
\hline & Transportasi & 50 & & \\
\hline & Profit Margin & 50 & 2,8 & \\
\hline & Margin Pemasaran & 150 & 8,6 & \\
\hline \multirow[t]{8}{*}{3.} & Pedagang Pengecer & & & 90 \\
\hline & Harga Jual & 1.900 & & \\
\hline & Bongkar & 25 & & \\
\hline & Muat & 25 & & \\
\hline & Plastik & 10 & & \\
\hline & Biaya tak terduga (dll) & 50 & & \\
\hline & Profit Margin & 65 & 3,4 & \\
\hline & Margin Pemasaran & 175 & 9,2 & \\
\hline 4. & Harga Beli Konsumen & 1.900 & & \\
\hline
\end{tabular}

Sumber : Data Primer (diolah), 2015

Berdasarakan Tabel 5. diatas terlihat bahwa harga jual pupuk urea oleh produsen pupuk adalah Rp. $1.575 / \mathrm{Kg}$, harga jual pedagang besar kepada pedagang pengecer adalah Rp. $1.725 / \mathrm{Kg}$. Lalu pedagang pengecer menjual kepada petani atau konsumen akhir dengan harga Rp. $1.900 / \mathrm{Kg}$, adapun harga tersebut tidak sesuai dengan Harga Eceran Tertinggi (HET) yang telah ditetapkan oleh pemerintah yaitu Rp. $1.800 / \mathrm{Kg}$, hal ini disebabkan dengan tingginya biaya pemasaran yang harus

Analisis Pemasaran Pupuk Urea di Kabupaten Pidie (Studi Kasus Produk PT. Pupuk Iskandar 310 Muda Aceh Utara) (Zeveni Zulisma Sari, Edy Marsudi, Sofyan)

Jurnal Ilmiah Mahasiswa Pertanian Unsyiah, Vol. 2, No. 4, November 2017: 300-314 
dikeluarkan oleh pedagang pengecer dalam memasarkan pupuk urea hingga sampai ke tangan konsumen akhir, yang mengharuskan pedagang pengecer untuk menaikkan harga penjualannya. Margin pemasaran di tingkat pedagang besar yaitu Rp. 150/Kg lebih kecil jika dibandingkan dengan pedagang pengecer yaitu $\mathrm{Rp}$. $175 / \mathrm{Kg}$. Sedangkan jumlah profit margin ditingkat pedagang besar adalah $\mathrm{Rp}$. $50 / \mathrm{Kg}$ yang berarti lebih rendah dibandingkan dengan profit margin yang diterima oleh pedagang pengecer senilai Rp. $65 / \mathrm{Kg}$

\section{Faktor-faktor Kelangkaan Pupuk Urea}

Dari hasil penelitian dilapangan hanya beberapa sampel saja yang bersedia mamberikan argumentasinya terhadap permasalahan kelangkaan pupuk urea di Kabupaten Pidie. Beberapa faktor tersebut adalah :

\section{Realisasi Penyaluran Pupuk Tidak Sesuai Dengan Kebutuhan Petani}

Kurangnya persediaan pupuk yang disediakan disuatu tempat telah banyak dikeluhkan oleh petani maupun pedagang.dalam hal ini petani menyalahkan pedagang sedangkan pedagang menyalahkan produsen. Padahal PT.PIM telah mengalokasikan pupuk urea ke seluruh wilayah pemasaran sesuai dengan prosedur dan aturan yang telah ditetapkan oleh pemerintah setempat.

Bahkan PT. PIM selalu melakukan realokasi kembali setiap bulannya karena adanya permintaan pupuk urea tambahan dari petani padahal PT. PIM sudah memenuhi total kebutuhan pupuk urea disetiap periode masa tanam. Seharusnya pemerintah harus menambah jumlah kuota kebutuhan pupuk dalam RDKK. Dengan penambahan kuota tersebut diharapkan pupuk akan selalu tersedia digudang pedagang besar dan pedagang pengecer.

Tabel 6. Kebutuhan Pupuk Urea Berdasarkan Luas Lahan Petani (Ha) Menurut Rekapitulasi pada Pedagang Besar di Kabupaten Pidie/Tahun

\begin{tabular}{|c|c|c|}
\hline Sampel (orang) & $\begin{array}{l}\text { Luas Lahan } \\
\text { Petani (Ha) }\end{array}$ & $\begin{array}{l}\text { Kebutuhan Pupuk } \\
\text { Urea (Ton) }\end{array}$ \\
\hline 1 & 20.476 & $4.262,25$ \\
\hline 2. 2 & 8.909 & $2.448,49$ \\
\hline 3 & 10.256 & $2.169,74$ \\
\hline 4. 4 & 5.373 & $3.082,64$ \\
\hline Total & 45.014 & $11.963,12$ \\
\hline Realisasi Pupuk Urea (Ton) & & $7.037,00$ \\
\hline Persentase $(\%)$ & & 58,8 \\
\hline Minus Pupuk Urea (Ton) & & $-4.926,12$ \\
\hline Minus Persentase (\%) & & $-41,2$ \\
\hline
\end{tabular}

Sumber : Data Primer (diolah), 2016

Berdasarkan tabel 6. Dapat terlihat bahwa total luas lahan di kabupaten Pidie adalah 45.015 Ha dengan jumlah kebutuhan pupuk urea dalam setahun adalah

Analisis Pemasaran Pupuk Urea di Kabupaten Pidie (Studi Kasus Produk PT. Pupuk Iskandar 311 Muda Aceh Utara) (Zeveni Zulisma Sari, Edy Marsudi, Sofyan)

Jurnal Ilmiah Mahasiswa Pertanian Unsyiah, Vol. 2, No. 4, November 2017: 300-314 
11.963,12 Ton, sedangkan pupuk urea yang disediakan oleh PT. PIM hanya 58,8\% dari total kebutuhan secara keseluruhan. PT. PIM hanya mampu memenuhi kebutuhan pupuk urea sebanyak 7.037,00 Ton sehingga jumlah kekurangan pupuk adalah $4.926,12$ Ton atau $41,2 \%$ setiap tahunnya. Hal ini dapat menyebabkan terjadinya kelangkaan pupuk urea yang selama ini sering terjadi di kabupaten Pidie.Dengan demikian tidak heran jika pedagang besar selalu meminta tambahan kuota pupuk urea setiap bulannya.

\section{Adanya Pihak-pihak yang Melakukan Penyimpangan atau Kecurangan}

Seperti adanya pihak-pihak yang menjual pupuk urea ke luar daerah tanggung jawabnya atau ke kabupaten lain yang kekurangan pupuk urea sehingga pada saat petani di wilayah pendistribusiannya membutuhkan pupuk dan pupuk tersebut tidak tersedia.Berujung pada pembelian secara terus menerus oleh petani yang disebut dengan istilah buying panic akibat meluasnya issue tentang kelangkaan pupuk urea, sehingga petani secara berbondong-bondong membeli pupuk urea dalam jumlah yang besar.

Pedagang dan petani selalu mengesalkan keterlambatan pupuk urea tersedia di gudang, padahal keterlambatan PT.PIM dalam menunjuk pedagang besar yang bertugas menyalurkan pupuk ke wilayah tersebut diakibatkan oleh terlambatnya pengeluaran Surat Keterangan (SK) dari Gubernur.

Bahkan ada beberapa opini dari masyarakat tentang factor ini, seperti menurut Bapak Ketua LSM (Lembaga Swadaya Masyarakat) JARA (Jaringan Aspirasi Rakyat Aceh) Iskandar Ar. Rahman S.Pd mengatakan "Kami minta kepolisian setempat agar kasus ini benar-benar diusut tuntas dan memproses siapapun yang terlibat tanpa pandang bulu". Berdasakan ketentuan pemerintah, pupuk bersubsidi tersebut sudah ditetapkan jatah kuota untuk masing-masing daerah dan tidak boleh diperjualbelikan secara bebas ke daerah lain. Bapak Iskandar menduga, selama ini kasus jual beli pupuk bersubsidi sudah marak terjadi, namun secara terstruktur sehingga aksi mereka berjalan mulus.Bahkan beliau mensinyalir keterlibatan oknum instansi terkait. (Aceh Journal National Network, www.ajnn.net, 2016).

\section{Lemahnya Pengawasan Dari Pihak Produsen dan Pemerintahan Setempat}

Tidak maksimalnya system pengawasan menjadi masalah pokok hampir disetiap kabupaten di provinsi Aceh khususnya di Kabupaten Pidie. Yang bertugas menjalankan pengawasan tersebut adalah tim dari kejaksaan, polisi dan dinas pertanian sering disebut dengan Komisi Pengawasan Pupuk dan Pestisida (KP3). Dalam melaksanakan tugas pengawasan yang dijalankan setiap 3 bulan sekali ini, sangat mengecewakan pihak petani bahkan setiap kedatangan dari tim pengawas telah diketahui terlebih dahulu oleh pedagang. Sehingga semua permasalahan sudah diatasi sebelum tim pengawas tersebut sampai di tempat pedagang. seharusnya tim pengawas lebih mengawasi lagi proses pelaksanaan jika ingin bertugas dengan baik, apakah pendistribusian pupuk sudah sampai ke tangan petani sesuai dengan yang

Analisis Pemasaran Pupuk Urea di Kabupaten Pidie (Studi Kasus Produk PT. Pupuk Iskandar 312 Muda Aceh Utara) (Zeveni Zulisma Sari, Edy Marsudi, Sofyan)

Jurnal Ilmiah Mahasiswa Pertanian Unsyiah, Vol. 2, No. 4, November 2017: 300-314 
diharapkan oleh pemerintah yaitu memenuhi prinsip 6 tepat : jenis, jumlah, harga, tempat, waktu dan mutu.

Sumber dari salah satu Responden Pedagang Besar mengatakan, "Tim pengawas hanya berkunjung setiap 3 bulan sekali saja, hal ini dapat mengakibatkan lembaga pemasaran tidak terlalu cemas ketika kedatangan tim pengawas tiba. Disebabkan kedatangannya secara tiba-tiba dan terlampau jarak yang cukup lama antara kunjungan pertama dengan kunjungan berikutnya itu sudah terlebih dahulu diprediksi oleh lembaga pemasaran, sehingga lembaga pemasaran tersebut bisa menstabilkan keadaan sebelum tim pengawas tiba".

\section{SIMPULAN DAN SARAN}

Bentuk saluran pemasaran pupuk urea bersubsidi yang dijalankan oleh PT. PIM di Kabupaten Pidie adalah bentuk saluran dua tingkat (Two-Level-Channel) yaitu Produsen (PT.PIM) - Pedagang Besar (Distributor) - Pedagang Pengecer (Kios) - Gapoktan (Konsumen).Margin pemasaran di tingkat pedagang besar adalah Rp. 150/Kg lebih kecil dibandingkan dengan margin pemasaran tingkat pedagang pengecer yaitu Rp. $175 / \mathrm{Kg}$, hal ini disebabkan tingginya biaya pemasaran yang harus dikeluarkan oleh pedagang pengecer dalam memasarkan pupuk urea PT. PIM.Ada beberapa faktor yang berperan dalam kelangkaan pupuk urea PT. PIM di Kabupaten Pidie, yaitu : realisasi penyaluran pupuk tidak sesuai dengan kebutuhan petani, adanya pihak-pihak yang melakukan kecurangan dan lemahnya pengawasan dari pihak produsen dan pemerintahan setempat.

Berdasarkan hasil penelitian, disarankan untuk PT. Pupuk Iskandar Muda Aceh Utara agar tetap mempertahankan hubungan kerjasama yang baik dengan pemerintah sehingga pupuk urea subsidi yang sangat dibutuhkan oleh petani dapat selalu tersedia.Untuk pedagang pupuk urea diharapakan agar bersedia menjual pupuk dengan harga yang telah ditetapkan oleh menteri perdagangan yaitu Rp. $1.800 / \mathrm{Kg}$ (HET), walaupun pupuk sering langka tapi pedagang tetap harus menjual dengan harga tersebut tidak boleh memanfaatkan situasi pasar yang demikian dengan menaikkan harga jual.Untuk pemerintah setempat seharusnya lebih mengupayakan sistem pengawasan yang lebih intensif dalam mengatasi masalah kelangkaan pupuk urea, sehingga tidak ada lagi isu-isu yang tersebar dikalangan petani dan pedagang pupuk urea tersebut. Pemerintah harus lebih tepat waktu dalam menjalankan mekanisme kebijakan penyaluran pupuk urea bersubsidi, sehingga keterlambatan pengiriman pupuk urea dari PT.PIM tidak terjadi lagi karena terlambatnya SK dari Gubernur

\section{DAFTAR PUSTAKA}

Firdaus, Muhammad, 2010. Manajemen Agribisnis. PT Bumi Aksara. Jakarta.

Kementerian Pertanian Republik Indonesia, 2013.Peraturan Menteri Pertanian Nomor: 69 / Permentan / SR. 130 / 11 / 2012. Menteri Pertanian. Jakarta.

Analisis Pemasaran Pupuk Urea di Kabupaten Pidie (Studi Kasus Produk PT. Pupuk Iskandar 313 Muda Aceh Utara) (Zeveni Zulisma Sari, Edy Marsudi, Sofyan)

Jurnal Ilmiah Mahasiswa Pertanian Unsyiah, Vol. 2, No. 4, November 2017: 300-314 
PT. Pupuk Iskandar Muda, 2014. Rekapitulasi RDKK Pupuk Urea. Aceh Utara.

PT. Pupuk Iskandar Muda, 2014. Pemasaran Urea. Aceh Utara.

PT. Pupuk Iskandar Muda, 2014. Prospek Perusahaan. Aceh Utara

PT. Pupuk Iskandar Muda, 2015. Annual Report. Aceh Utara. www.pim.co.id. Diaksespada 10 Agustus 2017. 